\title{
Phenotypic and Molecular Biological Analysis of Human Butyrylcholinesterase Variants
}

\author{
B.N. LA DU, ${ }^{1}$ C.F. BARTELS, ${ }^{1}$ C.P. NOGUEIRA, ${ }^{1}$ A. HAJRA, ${ }^{1}$ H. LIGHTSTONE, ${ }^{2}$ \\ A. VAN DER SPEK, ${ }^{3}$ and O. LOCKRIDGE ${ }^{1}$
}

\begin{abstract}
${ }^{1}$ Department of Pharmacology, University of Michigan Medical School, Ann Arbor, MI 48109-0626, USA; ${ }^{2}$ Department of Anesthesiology, Metropolitan Hospital, Philadelphia, PA 19106, USA; and ${ }^{3}$ Department of Anesthesiology, University of Michigan Medical School, Ann Arbor, MI 48109-0800, USA
\end{abstract}

\begin{abstract}
Our laboratory has recently shown that several variant forms of human butyrylcholinesterase, associated with unusual sensitivity to succinylcholine, are caused by specific mutations within the structural DNA coding for this enzyme. Atypical (dibucaine-resistant) butyrylcholinesterase is caused by a point mutation at nucleotide position 209(GAT-->GGT), which changes aspartate 70 to glycine. One fluoride-resistant variant family has a point mutation at nucleotide 728(ACG-->ATG), which changes threonine 243 to methionine. Another Type of Tuoride-resistant variant has a point mutation at nucleotide 1169(GGT-->GTT), which changes glycine 390 to valine. One type of silenf phenotype is due to a frame-shift mutation at nucleotide position 351(GGT-->GGAG). A polymorphic site at nucleotide position 1615 (GCAACA), coding for Ala/Thr, accounts for the quantitative $\mathrm{K}$-variant, which causes an approximate one-third reduction of activity, if Thr occupies that position at codon 539. Examples are given to illustrate the advantages of using a combination of the new DNA analytical techniques, including: the use of allele-specific probes, with the standard serum cholinesterase phenotyping methods. More accurate typing of patients with certain variants is now possible; pedigree analysis will be aided by the improved methodology.
\end{abstract}

KEY WORDS: butyrylcholinesterase variants; atypical variant; fluoride variant; $K$-variant; silent variant; structural DNA mutation; polymerase chain reaction; succinylcholine sensitivity.

\section{Introduction}

$\mathrm{H}$ uman serum butyrylcholinesterase ( $\mathrm{BChE}),{ }^{*}$ also called cholinesterase, pseudocholinesterase, and nonspecific cholinesterase (EC 3.1.1.8), is believed to be synthesized in the liver (1). In serum, it is present mainly as a tetrameric glycoprotein, containing four identical subunits; each subunit has one active catalytic site. The molecular weight of each subunit is 85,534 , and of the tetramer, $342,136(2)$.

Correspondence: Dr. B. N. La Du, Department of Pharmacology, Rm. 6322, Med. Sci. Bldg. I, University of Michigan Medical School, Ann Arbor, MI 48109-0626, USA.

Manuscript received October 26, 1989; revised January 16, 1990; accepted January 19, 1990.

*Editor's Footnote: In accordance with currently recommended nomenclature, the enzyme is abbreviated $\mathrm{BChE}$ and the gene, BCHE.

CLINICAL BIOCHEMISTRY, VOLUME 23, OCTOBER 1990
Of clinical interest is this enzyme's special role in the hydrolysis of drugs, such as, succinylcholine; and changes in its serum level, primarily decreases in activity caused by: liver disease, other generalized infectious diseases, and exposure to a number of drugs and agents, such as, the organophosphate insecticides (1).

A physiological function for serum $\mathrm{BChE}$ has not been clearly established. Recent studies suggest that $\mathrm{BChE}$ participates in neurotransmission in the smooth muscle of canine tracheal ring preparations (3). BChE and acetylcholinesterase are very similar in structure and properties (4). The two enzymes have a high degree of structural homology in their amino acid sequences; they presumably arose by gene duplication.

The importance of $\mathrm{BChE}$ in the hydrolysis of several drugs, particularly succinylcholine, is well established. The classical pharmacogenetic studies by Kalow et al., during the 1950's (5), made it clear that people with a hereditary deficiency in their serum BChE show an exaggerated response to succinylcholine, if given the standard amount of this muscle relaxant. These patients developed a prolonged paralysis of the respiratory muscles, and required artificial respiration for several hours, until the drug effects gradually wore off. Kalow and Genest (6) developed a simple serum test that detected the atypical $\mathrm{BChE}$, and thus identified the susceptible individuals, by the atypical $\mathrm{BChE}$ response to dibucaine (the Dibucaine Inhibition Test). The dose-response relationship between $\mathrm{BChE}$ activity and duration of clinical effects of succinylcholine has been carefully analyzed by Viby. Mogensen (7).

For much of the past 30 years, the dibucaine inhibition number, fluoride inhibition number, and a measurement of the level of serum BChE activity have provided sufficient information to identify most of the known $\mathrm{BChE}$ phenotypes associated with succinylcholine sensitivity. However, during the last 10-15 years, several additional $\mathrm{BChE}$ variants have been discovered. Most of these are rare; the $\mathrm{K}$ variant is the most common variant $(22 \%$ of the general population is heterozygous, and $1.5 \%$ ho- 
LA DU, BARTELS, NOGUEIRA, ET AL.

TABLE 1

Genetic Forms and Variants of Human Butyrylcholinesterase

\begin{tabular}{|c|c|c|}
\hline $\begin{array}{c}\text { Name and } \\
\text { Characteristics }^{\mathrm{a}}\end{array}$ & $\begin{array}{c}\text { Gene } \\
\text { Frequency }\end{array}$ & Investigators $^{\mathrm{b}}$ \\
\hline Usual & 0.870 & \\
\hline $\begin{array}{l}\mathrm{K} \text {-variant (quantitative; } \\
\text { activity reduced } 1 / 3 \text { ) }\end{array}$ & 0.113 & $\begin{array}{l}\text { Rubinstein et al. (8); } \\
\text { Whittaker and Britten (9) }\end{array}$ \\
\hline $\begin{array}{l}\text { Atypical (dibucaine- } \\
\text { resistant) }\end{array}$ & 0.017 & $\begin{array}{l}\text { Kalow and Staron (10); } \\
\text { Kalow and Gunn (11) }\end{array}$ \\
\hline $\begin{array}{l}\text { Silent (none, or very low } \\
\text { activity; several types) }\end{array}$ & $1: 100,000$ & Liddell et al. (12) \\
\hline Fluoride-resistant & $1: 150,000$ & Harris and Whittaker (13) \\
\hline $\begin{array}{l}J \text {-variant (quantitative; } \\
\text { activity reduced } 2 / 3 \text { ) }\end{array}$ & rare & $\begin{array}{l}\text { Gary et al. (14) } \\
\text { Evans and Wardell (15) }\end{array}$ \\
\hline $\begin{array}{l}\text { H-variant (quantitative; } \\
\text { activity reduced } 90 \% \text { ) }\end{array}$ & rare & Whittaker and Britten (16) \\
\hline Newfoundland & rare & Simpson and Elliot (17) \\
\hline Cynthiana (high activity) & 4 families & $\begin{array}{l}\text { Neitlich (18) } \\
\text { Whittaker (1) }\end{array}$ \\
\hline $\begin{array}{l}\text { German high activity } \\
\text { variant }\end{array}$ & 2 families & Delbruck and Henkel (19) \\
\hline $\begin{array}{l}\text { South African variant (high } \\
\text { activity; Johannesburg) }\end{array}$ & 1 family & Krause et al. (20) \\
\hline
\end{tabular}
${ }^{\mathrm{a}}$ Further details on these variants are given in (1). ${ }^{\mathrm{b}}$ Numbers in paren-
theses refer to reference citations.

mozygous for this variant). Total variants have increased to approximately 10 (Table 1) (8-20). The exact number is uncertain because it is not known whether all of these described, and given different names, represent entirely new types. The larger number of variants has greatly increased the complexity of phenotyping individuals. In fact, it is no longer possible to even predict the number of individuals expected for each genotype, because some of these unusual characteristics are inherited in tandem, due to linkage disequilibrium. Presently, the standard serum tests can clearly identify only about half of the $\mathrm{BChE}$ variants. The standard tests are particularly deficient in identifying the genotypes representing quantitative, rather than qualitative variants.

We will demonstrate how butyrylcholinesterase variants can be analyzed at the DNA level, and how new analytical methods, based upon this knowledge, are now being developed to improve and simplify the problem of identifying individual BChE phenotypes and genotypes.

\section{Background}

Butyrylcholinesterase is present in human serum in very low concentration (approximately $5 \mathrm{mg} / \mathrm{L}$ ); it has, therefore, been impractical to purify variant $\mathrm{BChE}$ enzymes from serum and identify the abnormalities directly in their amino acid composition. Thus, it was necessary to indirectly determine the structural defects in the variant enzymes by comparing the DNA sequence coding for the variant proteins with the corresponding sequence for the usual $\mathrm{BChE}$, to deduce the amino acid change in the variant proteins.

\section{ATYPICAL BUTYRYLCHOLINESTERASE}

The approach outlined above required that we determine the amino acid sequence of pooled usual human serum butyrylcholinesterase (21), clone the $\mathrm{BCHE}$ gene from a human brain cDNA library $(22,23)$, and identify the difference in the butyrylcholinesterase DNA sequence from a person homozygous for atypical BChE (24). Direct sequencing of the atypical genomic DNA revealed a change in only one of the 1722 nucleotide bases coding for 574 amino acids of the atypical $\mathrm{BChE}$ sub-unit. This point mutation, however, produced the critical difference in one of the atypical amino acid (dibucaineresistant) variant enzymes. The mutation was at nucleotide 209(GAT->GGT), which changed amino 


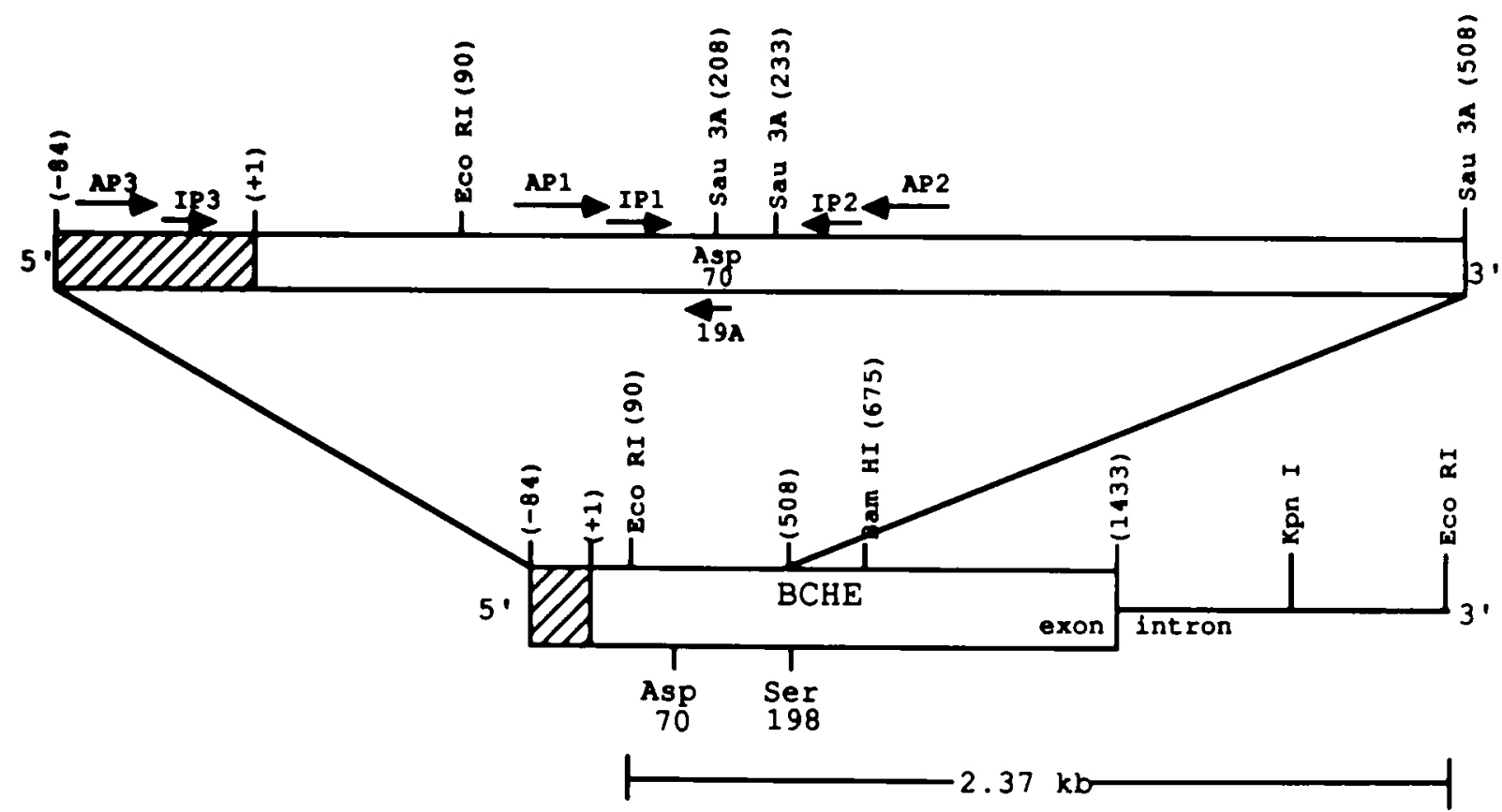

Figure 1-Schematic representation of exon 2 of the human butyrylcholinesterase gene. The hatched region represents the signal peptide. $70 \mathrm{Asp}$ is the site of the atypical cholinesterase mutation, and 198 Ser is the active center serine. AP1 and AP2 are the amplification primers for PCR amplification of the segment about the atypical mutation site, and IP1 and IP2 are the internal sequencing primers. From McGuire et al. (Ref. 24).

acid 70 from aspartate to glycine. To verify that this point mutation was consistently associated with the atypical characteristics, we examined over 30 additional atypical individuals (both homozygous and heterozygous for the atypical trait) from other families. To do this efficiently, and to avoid making genomic libraries for each person, we used the polymerase chain reaction (PCR) amplification tech- nique (24) to amplify a $187 \mathrm{bp}$ DNA segment, which bridges the region around nucleotide 209 (Figure 1). The amplified DNA fragments were directly sequenced using internal primers IP1 and IP2 (Figures 1 and 2). We demonstrated that this same point mutation occurred in single or double dose; this paralleled the heterozygous or homozygous atypical serum phenotype in every instance (24). The modi-

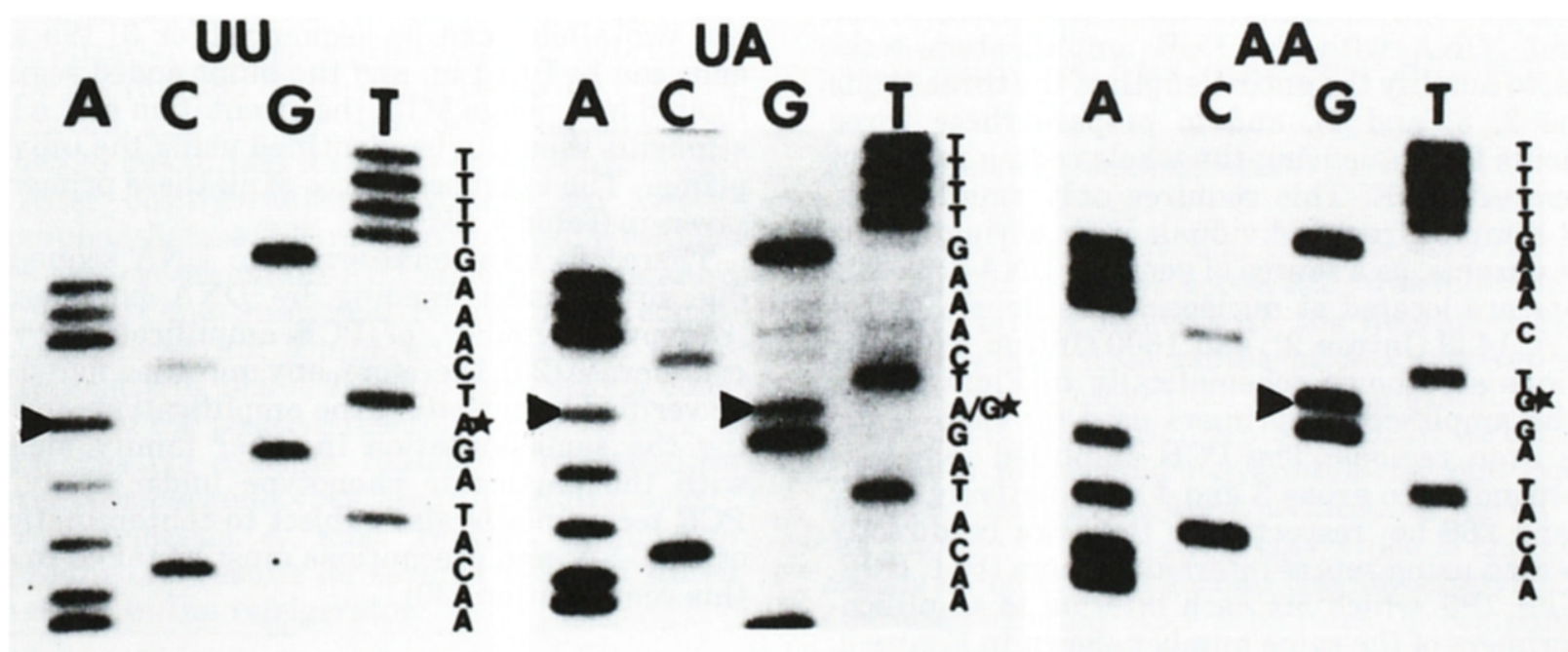

Figure 2-DNA sequences seen by direct sequencing of AP1 and AP2 PCR-amplified blood leukocyte genomic DNA from individuals representing the usual (UU, left); usual-atypical heterozygous (UA, middle), and atypical (AA, right) phenotypes. Arrows mark the nucleotides at position 209 characteristic of the corresponding genotypes. From McGuire $e t$ al. (Ref. 24). 


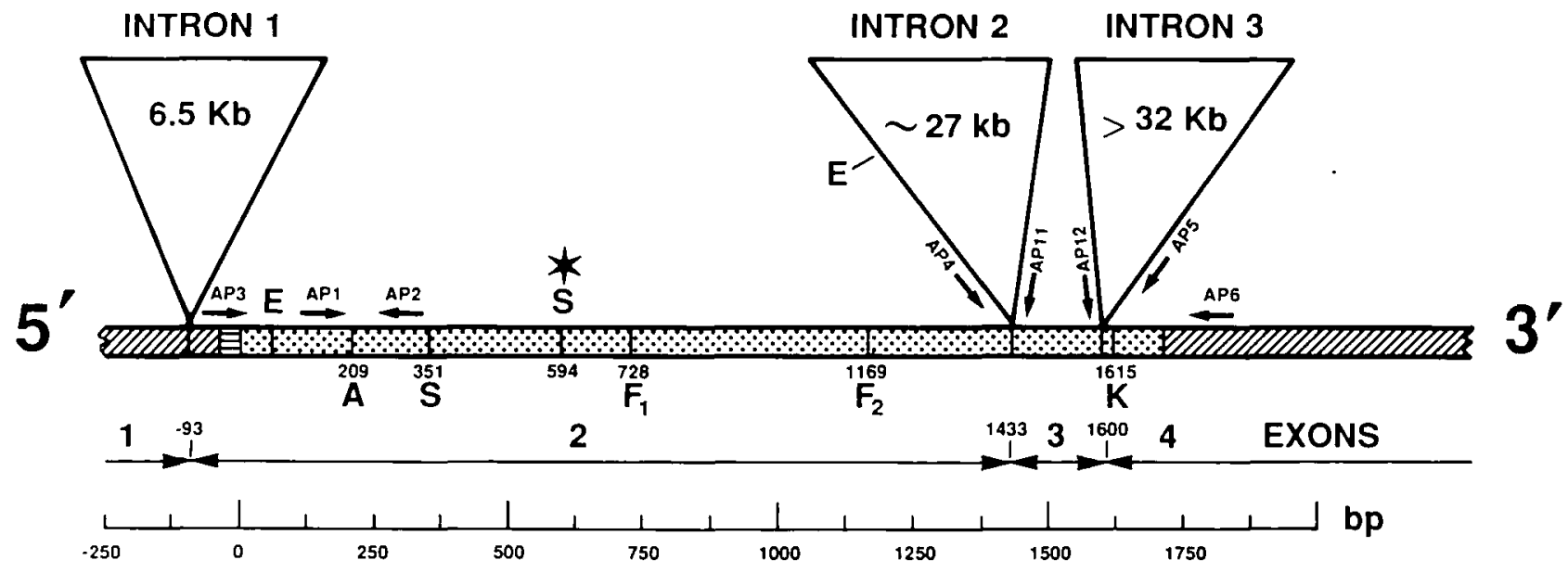

Figure 3-Structural characteristics of the human butyrylcholinesterase gene. The three introns are represented by triangles, and the coding region for the mature $\mathrm{BChE}$ protein is represented by the dotted portion. The leader sequence is indicated with horizontal bars. Amplification primers for exon 2 (AP3 and AP4), exon 3 (AP11 and AP12), and exon 3 (AP5 and AP6) are indicated by arrows. Modified from Ref. 27.

fication in structure (loss of an acidic residue; Asp to Gly) presumably affects the anionic site of the active center. This may be a reasonable explanation for the atypical enzyme's reduced affinity to choline esters, particularly succinylcholine. We conclude that Asp 70 occupies an important position within, or very near, the anionic site of human $\mathrm{ChE}$.

\section{OTHER STRUCTURAL VARIANTS}

We are currently using a similar approach to determine the DNA modification in a number of the other $\mathrm{BChE}$ variants.

We have determined the location and size of the three introns in the human BChE gene (25), and we have sequenced portions of the introns adjacent to the intron-exon junctions. Thus, it is practical to use genomic DNA with the PCR amplification technique, to amplify the entire length of the three exons (exons 2, 3, and 4), and to prepare these three segments for sequencing the whole coding region of the mature $\mathrm{ChE}$. This requires only small whole blood samples from individuals with variant forms of the enzyme, as a source of genomic DNA (26). The introns are located at nucleotide positions: -93 (Intron 1); 1433 (Intron 2); and 1600 (Intron 3). These positions are shown schematically in Figure 3 , as are the amplification primers used for each of the three exon regions. The PCR amplified segments corresponding to exons 3 and 4 are relatively short: 187 and $266 \mathrm{bp}$, respectively; they can be directly sequenced using sets of internal primers IP11, IP12, and IP5, IP6, which are each internal to amplification primers of the same number shown in Figure 3. Exon 2 is much longer, approximately $1.5 \mathrm{~kb}$. Even though we have had some success with direct sequencing using primers distributed every 200-300 bases along that segment, the PCR amplified DNA is generally not clean enough to give unambiguous direct sequencing information. Some of the variants to be analyzed are very rare, and available only in the heterozygous state. It is important, therefore, to have a very efficient method of examining the sequence of exon 2 from these variant samples, without confusion by shadow bands. The presence of an extra base (heterozygosity) at the same level as the wild type nucleotide is used to identify and characterize the variant allele (Figure 2 ).

As illustrated in Figure 3 (27), we amplify exon 2 with amplification primers AP3 and AP4; Each of these are constructed to contain a restriction site (Hind III and Kpn I, respectively), so that the amplified segment of approximately $1500 \mathrm{bp}$ can be: 1) sequenced directly with a series on internal sequencing primers located about every 200 bp apart; or 2) excised and ligated in a forced orientation in phage M13 (28), so that single strands, representing the two alleles can be sequenced; or 3) the sticky ends can be filled in, and the blunt ended segments ligated into phage M13; the orientation of the latter segments then can be identified using the universal primer. The exact sequences of all these primers are given in Table 1 (24).

There are occasional errors in DNA sequencing, due to incorrect reading by DNA polymerase I (Klenow fragment), or PCR amplification by Taq polymerase (29); therefore, any mutation found must be verified by repeating the amplification, and finding the same mutation in other family members with the particular phenotype under study. The PCR technique is also subject to contamination by other DNA, and precautions must be taken to avoid this complication (30).

\section{Methods}

Preparation of SPECIFIC PROBES AND PRIMERS

Oligonucleotides for DNA amplification, sequencing, and ${ }^{32} \mathrm{P}$ or biotin-labeled, allele-specific probes 
TABLE 2

Structural Basis of Some Human Butyrylcholinesterase Variants

\begin{tabular}{|c|c|c|c|c|}
\hline $\begin{array}{l}\text { Common } \\
\text { Name }\end{array}$ & $\begin{array}{l}\text { Phenotypic } \\
\text { Description }\end{array}$ & $\begin{array}{c}\text { Recommended } \\
\text { Name }\end{array}$ & $\begin{array}{c}\text { Protein } \\
\text { Alteration } \\
\text { (Amino Acid } \\
\text { Change) }\end{array}$ & $\begin{array}{c}\text { DNA Mutation } \\
\left(5^{\prime} \text { to } 3^{\prime}\right)\end{array}$ \\
\hline Atypical & $\begin{array}{l}\text { Dibucaine- } \\
\text { Resistant }\end{array}$ & Atypical-1 & 70 Asp->Gly & $\mathrm{nt} 209(\mathrm{GAT}$ to GGT) \\
\hline Silent & $\begin{array}{l}\text { Silent, No } \\
\text { Activity }\end{array}$ & Silent-1 & $\begin{array}{c}117 \text { Gly-> Frame } \\
\text { Shift }\end{array}$ & $\mathrm{nt} 351$ (GGT to GGAG) \\
\hline Fluoride & $\begin{array}{l}\text { Fluoride- } \\
\text { Resistant }\end{array}$ & Fluoride-1 & 243Thr->Met & nt728 (ACG to ATG) \\
\hline Fluoride & $\begin{array}{l}\text { Fluoride- } \\
\text { Resistant }\end{array}$ & Fluoride-2 & $390 \mathrm{Gly}->\mathrm{Val}$ & nt1169(GGT to GTT) \\
\hline $\mathrm{K}$-variant & K-polymorphism & $\mathrm{K}$-variant & 539Ala->Thr & $\mathrm{nt} 1615$ (GCA to $\mathrm{ACA})$ \\
\hline
\end{tabular}

From Ref. 32.

were synthesized by the University of Michigan DNA Synthesis Facility. In some instances, the oligonucleotides were purified on HPLC in our laboratory. We prepared 19-mer, allele-specific, oligonucleotide probes, biotinylated at the 5' terminus (31), with the center nucleotide complementary to the mutant, or wild type nucleotide.

\section{ASSAYS WITH ALLELE-SPECIFIC, BIOTIN-LABELED PROBES}

This method will be published in detail, but the principle is summarized as follows: Hind III digested genomic DNA segments about 200 nucleotides in length (which contain the region of the point mutation), are amplified by the PCR technique; duplicate aliquots of the amplification mixture are dot blotted on nitrocellulose sheets. The DNA dots are cut out in $1 \mathrm{~cm}^{2}$ squares; each is placed in its own well in a multicompartment, tissue culture plastic dish. After prehybridization washes, each sample is hybridized with the appropriate biotinylated probe for $1 \mathrm{~h}$, at a temperature, and buffered salt concentration predetermined to be optimal for allele-specific hybridization. After posthybridization washes, an avidinalkaline phosphatase (AP) reagent is added. Washings remove any excess avidin-AP reagent; the standard AP substrate and analytical reagents are added. Color appears within $5 \mathrm{~min}$, and reaches a maximum intensity at about $20 \mathrm{~min}$, with strong color (dark blue) in the positive reaction wells; no color is seen in negative controls. Standards representing the three possible genotypes, are run simultaneously with each analysis. A "stop" reagent is added to preserve the test results for several weeks, if stored in the dark, in the refrigerator.

\section{Results}

\section{PRELIMINARY RESULTS ON OTHER VARIANTS}

In addition to the DNA alteration responsible for the atypical variant, we have found several other mutations that account for other $\mathrm{BChE}$ variants (Table 2) (32).

\section{ONE TYPE OF SILENT PHENOTYPE}

A frame-shift mutation at nucleotide position 351 , which changes codon 117 from GCT to GGAG $(24,33)$, explains one type of silent phenotype. Presumably there are several molecular types of silent mutations (1). Since the frame-shift mutation creates a stop codon, approximately 12 amino acids farther along, the mutant sequence could not produce any active $\mathrm{BChE}$. Evidence now supports that there is only a single gene for human $\mathrm{BChE}$ (25). Individuals homozygous for this silent mutation should have no active cholinesterase in their tissues. Two members of one pedigree are homozygous for this defect; they will be ideal subjects to investigate any reasonable theories concerning possible physiological functions of $\mathrm{BChE}$.

\section{TWo TYPES OF FLUORIDE-RESISTANT VARIANTS}

One structural mutation at nucleotide 728(ACG to ATG; Thr to Met at codon 243) was found in two members of one family with the fluoride-resistant trait. However, this mutation has not yet been detected in any other fluoride variant families. Until we find it in at least one other family, we consider it to be a provisional explanation for one type of fluoride variant. We are convinced, however, that the fluoride variant phenotype, which is characterized by a higher than normal $\mathrm{Km}$ for benzoylcholine and other choline ester substrates, is composed of more than one DNA defect.

Recently, we identified another point mutation in members of another family carrying the fluoride variant. This mutation affects amino acid 390 , and changes glycine to valine (Table 2). We are currently examining members of other families pheno- 


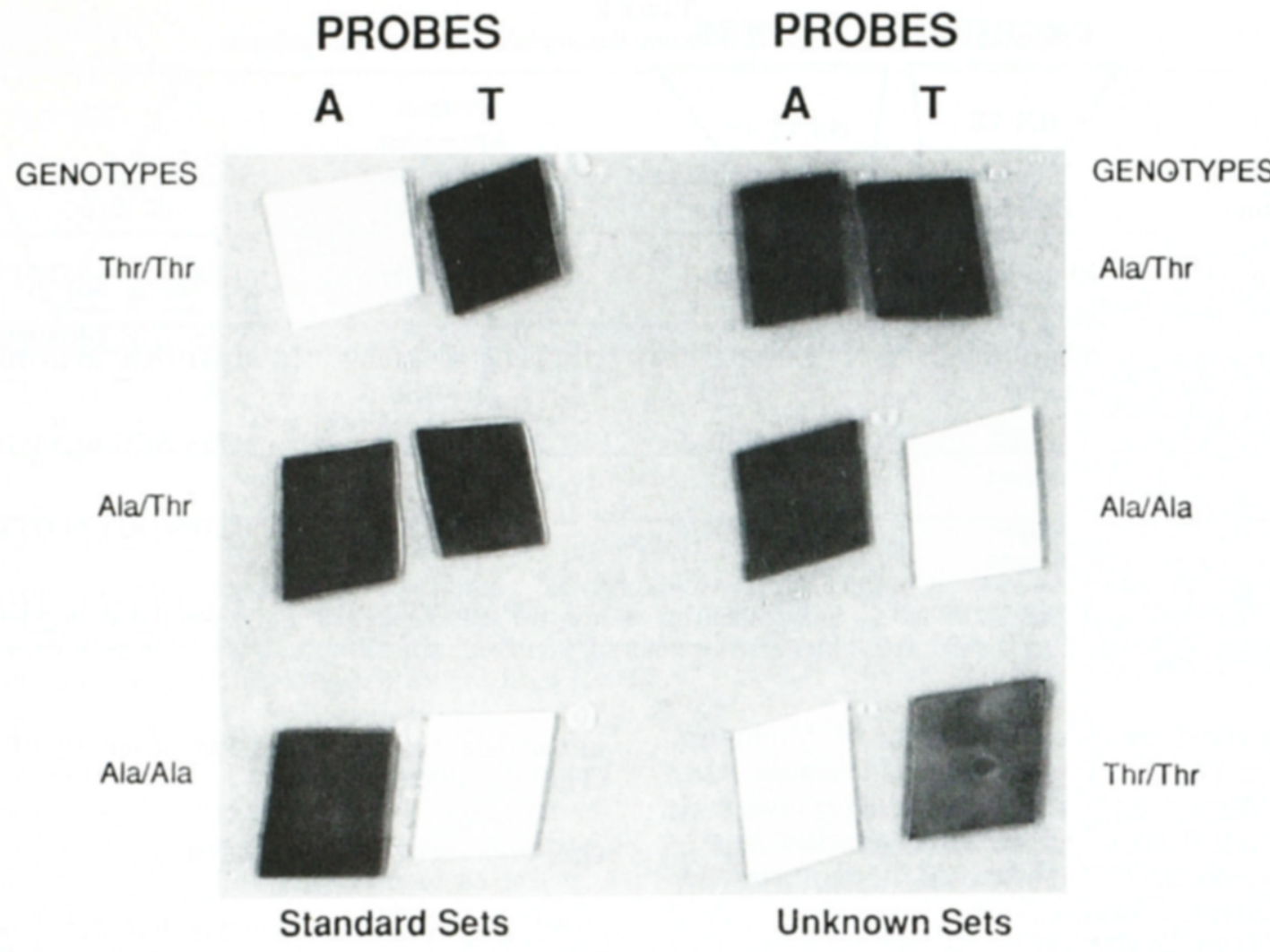

Figure 4-Analysis of the Ala/Thr polymorphism with allele specific, biotinylated 19-mer oligonucleotide probes. This polymorphism is determined by the particular nucleotide at position 1615: GCA codes for 539 Ala, and ACA for 539 Thr. The BChE K-variant is characterised by threonine at this location (34). Probe $\mathrm{A}=\mathrm{Ala}$-specific probe; Probe $\mathrm{T}=$ Thr-specific probe. 3 Standard genotype sets, tested with both probes, are shown on the left: Homozygosity for Thr is illustrated at the top; heterozygosity (Thr/Ala) in the middle, and homozygosity for Ala at the bottom. Three unknown DNA samples are analyzed with both probes on the right: The upper set is from a heterozygous individual, the middle set is from a person homozygous for Ala, and the lower set is from a person homozygous for Thr. These probe test results were verified by directly sequencing the amplified DNA.

typed as fluoride-resistant variants, to determine if they have either of the two above-mentioned mutations.

\section{THE K-VARIANT}

The structural basis for the K-variant was discovered unexpectedly (34). When we were analyzing the DNA basis for possible polymorphic sites in the $\mathrm{BChE}$ coding region, and measuring the allelic frequencies, one was identified at nucleotide 1615 (in exon 4). The polymorphic forms of the enzyme (Ala/ Thr) at position 539 depend on the nucleotide base present at position 1615 (GCA/ACA, respectively) (34). We noted that the frequencies of the two alleles, determined by analyzing the DNA sequence at 1615 after PCR amplification of exon 4 in 40 normal people, were 0.1125 and 0.8875 for the bases coding for Thr and Ala, respectively. This agreed very closely with the gene frequency calculated for the K-variant (9), if Thr at position 539 produced $\mathrm{BChE}$ with $\mathrm{K}$-variant characteristics: one-third less activity, but having the same quality as usual $\mathrm{BChE}$ (8). Additional studies in recent months have supported this hypothesis.

Until now, phenotyping the $\mathrm{K}$-variant in serum samples has been very difficult; it could be identified only in combination with the atypical allele (AK). This mixture should have a lower dibucaine number than AU serum: approximately 56, rather than 62 . When the $\mathrm{K}$-variant is present alone (homozygous $\mathrm{KK}$ ), or in combination with usual $\mathrm{BChE}$, (UK), the $\mathrm{K}$-variant confers no unusual, qualitatively different features; (UK) serum would be typed as (UU) serum. Since it is a quantitative variant, it seems very unlikely that any suitable method, based upon substrates or inhibitors, is likely to be successful in identifying the $\mathrm{K}$-variant by a serum phenotyping test. The active center and kinetic properties of the $\mathrm{K}$-variant appear to be identical with the usual enzyme.

For this reason, we recently prepared allele-specific, nonradioactive, biotinylated probes for the DNA sequences responsible for the two alternative amino acids at the 539 polymorphic site (Figure 4). 
We can now type individuals for the $\mathrm{K}$-variant by amplifying the $266 \mathrm{bp}$ segment of digested genomic DNA from blood leukocytes by the PCR, and by hybridizing with the above probes. There has been perfect agreement between this new method with the allele-specific probes and analysis by direct sequencing of that DNA region. Typing of the $\mathrm{K}$ variant by this new technique will allow us to determine whether the $\mathrm{K}$-variant occurs regularly with other BChE variants, and allow us to study the observed linkage disequilibrium between the atypical and K-variants. Over $90 \%$ of the atypical mutations have been linked in tandem with the $\mathrm{K}$ variant.

For the first time, it is possible to identify individuals who are homozygous for the K-variant, and who have the usual BChE phenotype. The $\mathrm{K}$-variant is not only the most frequently found variant of $\mathrm{BChE}$ yet identified, but it represents one of the most common enzyme polymorphisms in man. Its significance is entirely unknown.

\section{Allele-SPECIFIC PROBE for the atypiCAl MUtation}

We have also developed a biotinylated, allelespecific probe for the atypical allelic sequence. We will use it to identify any atypical phenotypes that might arise from a mutation different than the regularly encountered nucleotide 209 defect. This probe will also make it possible to identify which atypical subjects are actually atypical silent (AS), rather than homozygous atypical (AA), based on their genetic heterozygosity. They should be UA at the 209 nucleotide position, even though their serum phenotype would be like that of an (AA) homozygous person. For the first time, the above combination of allele specific probes and serum phenotyping permits a diagnostic test capable of distinguishing between (AS) and (AA) genotypes. This may be useful in the analysis of some pedigrees, and in counseling patients and their relatives about possible sensitivity to the drug, succinylcholine.

\section{Discussion}

It is now useful to establish DNA structural criteria for classifying the genotypes responsible for the various human serum BChE phenotypes because: 1 ) a growing number of variants make it more difficult to be sure that any additional variants reported are really new, and represent different structural mutations than those already known; 2) it is difficult to detect quantitative variants by any of the present serum phenotyping methods. Unlike the hemoglobins and a number of the red blood cell enzymes (such as glucose-6-phosphate dehydrogenase), which have many variant forms that have been generally characterized by their differences in amino acid sequence, the $\mathrm{BChE}$ variants occur in such low concentration in serum that it is easier to move directly to a structural classification, based on their DNA sequence. If the series of quantitative variants (K-, J-, H-, and others) differ primarily in regions which affect the half life, or stability of the enzyme, but do not influence the catalytic activity, it is doubtful that any practical phenotyping method can be developed for their identification by simple serum testing. For these variants, the use of nonradioactive, colorimetric, allele-specific probes will probably become the detection method of choice within a few years.

Variants that differ catalytically from the usual $\mathrm{BChE}$, because of $\mathrm{Km}$ or $\mathrm{Ki}$ differences with selective substrates or inhibitors (i.e., atypical, and the fluoride variants), will continue to be detected most conveniently by the present or improved phenotyping tests with serum. The allele-specific probes should be helpful in developing more selective phenotyping methods, because the probes can identify which sera represent the different subtypes, based on particular DNA mutations. The challenge will be to see whether the subtypes can be distinguished by improved catalytic tests. We are studying the two (or more) subtypes of fluoride-resistant variants in this respect.

Another application of the allele-specific probes will be to distinguish various subtypes within the silent phenotype. Presumably, several different silent genotypes are represented (35). This conclusion is based upon immunotitration of the crossreacting material, and measurement of the very low, as opposed to no, BChE activity in sera.

A further advantage of the DNA-based classification of the cholinesterase variants is that designation of BChE phenotypes, by the currently used standards, assumes that all the variants represent allelic alternatives at the same genetic locus; thus, identification of any two such variant traits defines a person's BChE genotype. Our preliminary studies show that the "allelic" traits are each determined by specific point mutations, or changes in a few bases, at particular sites within the coding region of the $\mathrm{BChE}$ gene. Thus, several $\mathrm{BChE}$ structural mutations can co-exist independently, on the same chromosomal strand. Being "atypical" (Gly at amino acid residue 70 ) does not exclude also having the $\mathrm{K}$ variant (Thr at amino acid residue 539) on the same piece of DNA. The exact locations of the point mutations are distinct, but very closely linked within the BChE genome; this accounts for the pronounced linkage disequilibrium we have observed. This, of course, would be expected for such closely linked genetic markers.

Clearly, clinical laboratories will need to perform both standard phenotyping methods with the serum $\mathrm{BChE}$ and the new DNA structural analyses, using blood cell genomic DNA, PCR amplification, and allele-specific probes to diagnose some of the genotypes responsible for BChE variants.

Lastly, the new methods we are developing for identification of $\mathrm{BChE}$ mutations at the DNA level, and their detection with nonradioactive, allele-spe- 
cific probes, should have wide applicability for many other inherited metabolic disorders, abnormalities in drug metabolism enzymes, and other pharmacogenetic conditions caused by point mutations, frameshift mutations, or deletions in the DNA coding for enzymes and receptor proteins.

\section{Acknowledgement}

Support of NIH grant 27028 is gratefully acknowledged.

\section{Justification of authorship}

In accordance with Journal Policy, the senior author was asked to describe the contributions of the other named authors and did so as follows:

C.F. Bartels did much of the sequencing work, discovered the $\mathrm{K}$-variant and one of the fluorideresistant variants, and sequenced $\mathrm{BChE}$ exon 4 from 40 unrelated people to determine the allelic frequency for the $\mathrm{K}$-variant.

C.P. Nogueira optimized the PCR amplification metbod developed, and used, to establish the DNA basis for butyrylcholinesterase mutations.

A. Hajra made the biotinylated allele-specific probes corresponding to several of the $\mathrm{BChE}$ variants, and provided the results with the $\mathrm{K}$-variant presented in Figure 4.

H. Lightstone and A. van der Spek are clinical collaborators and anesthesiologists who sent many blood samples from patients showing unusual reactions to succinylcholine, worked out the family pedigrees of interesting cases, and obtained plasma samples from other relatives.

$\mathrm{O}$. Lockridge determined the complete amino acid sequence of butyrylcholinesterase and introduced the methodology used to clone the human $\mathrm{BChE}$ gene.

\section{References}

1. Whittaker, M. Cholinesterase. In: Beckman L., ed. Monographs in human genetics. Vol. 11. Basel, Switzerland: Karger, 1986.

2. Lockridge O, Eckerson HW, La Du BN. Interchain disulfide bonds and subunit organization in human serum cholinesterase. $J$ Biol Chem 1979; 254: 832430.

3. Adler M, Reutter SA, Filbert MG. Regulation of acetylcholine hydrolysis in canine tracheal smooth muscle. Fund Appl Toxicol (in press).

4. Chatonnet A, Lockridge O. Comparison of butyrylcholinesterase and acetylcholinesterase. Biochem $J 1989$; 260: 625-34.

5. Kalow W. Pharmacogenetics: Heredity and the response to drugs. Pp. 69-93. Philadelphia: W. B. Saunders, 1962.

6. Kalow W, Genest K. A method for the detection of atypical forms of human serum cholinesterase. Determination of dibucaine numbers. Can $J$ Biochem 1957; 35: 339-46.

7. Viby-Mogensen J. Correlation of succinylcholine duration of action with plasma cholinesterase activity in subjects with the genotypically normal enzyme. Anes- thesiology 1980; 53: 517-20.

8. Rubinstein HM, Dietz AA, Lubrano T. Ek, another quantitative variant at cholinesterase locus $1 . \mathrm{J} \mathrm{Med}$ Genet 1978; 15: 27-9.

9. Whittaker M, Britten JJ. Plasma cholinesterase variants. Family studies of the Ek gene. Human Hered 1985; 35: 364-8.

10. Kalow W, Staron N. On distribution and inheritance of atypical forms of human serum cholinesterase, as indicated by dibucaine numbers. Can J Biochem 1957; 35: $1305-20$.

11. Kalow W, Gunn DR. Some statistical data on atypical cholinesterase of human serum. Ann Hum Genet 1959; 23: 239-50.

12. Liddell J, Lehmann H, Silk E. A silent pseudocholinesterase gene. Nature 1962; 193: 561-2.

13. Harris $H$, Whittaker $M$. Differential inhibition of human serum cholinesterase with fluoride: recognition of two new phenotypes. Nature 1961; 191: 3898904

14. Garry PJ, Dietz AA, Lubrano T, Ford PC, James K, Rubinstein HM. New allele at cholinesterase locus 1 . J Med Genet 1976; 13: 38-42.

15. Evans RT, Wardell J. On the identification and frequency of the $J$ and $K$ cholinesterase phenotypes in a Caucasian population. $J$ Med Genet 1984; 21: 99-102.

16. Whittaker M, Britten JJ. Plasma cholinesterase variants. EH, a new allele at cholinesterase locus 1 . Human Hered 1987; 37: 54-8.

17. Simpson NE, Elliot CR. Cholinesterase Newfoundland: a new succinylcholine-sensitive variant of cholinesterase at locus 1. Am J Human Genet 1981; 33: 366-74.

18. Neitlich HW. Increased plasma cholinesterase activity and succinylcholine resistance: a genetic trait. $J$ Clin Invest 1966; 45: 380-7.

19. Delbruck A, Henkel E. A rare genetically determined variant of pseudocholinesterase in two German families with high plasma enzyme activity. Eur $J$ Biochem 1979; 99: 65-9.

20. Krause $A$, Lane $A B$, Jenkins $T$. A new high activity plasma cholinesterase variant. J Med Genet 1988; 25: $677-81$.

21. Lockridge O, Bartels CF, Vaughan TA, et al. Complete amino acid sequence of human serum cholinesterase. I Biol Chem 1987; 262: 549-57.

22. McTiernan C, Adkins S, Chatonnet A, et al. Brain cDNA clone for human cholinesterase. Proc Natl Acad Sci USA 1987; 84: 6682-6.

23. Prody CA, Zevin-Sonkin D, Gnatt A, Goldberg O, Soreq $\mathrm{H}$. Isolation and characterization of full-length cDNA clones coding for cholinesterase from fetal human tissues. Proc Natl Acad Sci USA 1987; 84: 3555-9.

24. McGuire MC, Nogueira CP, Bartels CF, et al. Identification of the structural mutation responsible for the dibucaine-resistant (atypical) variant form of human serum cholinesterase. Proc Natl Acad Sci USA 1989; 86: $953-7$.

25. Arpagaus M, Kott M, Vatsis KP, Bartels CF, La Du $\mathrm{BN}$, Lockridge $\mathrm{O}$. Structure of the gene for human butyrylcholinesterase. Evidence for a single copy. Biochemistry (in press).

26. Kunkel LM, Smith KD, Boyer SH, et al. Analysis of human Y-chromosome-specific reiterated DNA in chromosome variants. Proc Natl Acad Sci USA 1977; 74: $1245-9$.

27. La Du BN. Identification of human serum cholinest- 
erase variants using the polymerase chain reaction amplification technique. Trends Pharmacol Sci 1989; 10: 309-13.

28. Ginsburg D, Konkle BA, Gill JC, et al. Molecular basis of human von Willebrand disease: analysis of platelet von Willebrand factor mRNA. Proc Natl Acad Sci USA 1989; 86: 3723-7.

29. Tindell KR, Kunkel TA. Fidelity of DNA synthesis by the Thermus aquaticus DNA Polymerase. Biochemis. try 1988; 27: 6008-13.

30. White TW, Arnheim N, Erlich HA. The polymerase chain reaction. Trends Genetics $1989 ; 5$; 185-8.

31. Chu BCF, Orgel LE. Detection of specific DNA sequences with short biotin-labeled probes. DNA 1985; 4: $327-31$.
32. La Du BN, Bartels CF, Nogueira CP. Arpagaus M, Lockridge $\mathrm{O}$. Proposed nomenclature for human butyrylcholinesterase genetic variants identified by DNA sequencing. Cell Molec Biol (in press).

33. Nogueira CP, McGuire MC, Bartels C, et al. Identification of a frameshift mutation responsible for the silent phenotype of human serum cholinesterase, (Gly 117, GGT-->GGAG). Am J Human Genet (in press).

34. Bartels CF, Van der Spek A, Lockridge O, La Du BN. A polymorphism (K-variant?) of human serum cholinesterase at nucleotide 1615 , coding for Ala/Thr 539. FASEB J 1989; 3: 741A.

35. Altland $\mathrm{K}$, Goedde WH. Heterogeneity in the silent gene phenotype of pseudocholinesterase of human serum. Biochem Genet 1970; 4: 321-38. 